\title{
Pengaruh Penggunaan Kontekstual dan Keterampilan Berpikir Tingkat Tinggi (HOTS) terhadap Kemampuan Menulis Puisi pada Siswa Kelas IV SDN Se-Gugus I Karanganyar Kabupaten Ngawi Tahun Ajaran 2021/2022
}

\author{
Elia Widyastuti Parmadi $\bowtie$, Universitas PGRI Madiun \\ V. Teguh Suharto, Universitas PGRI Madiun \\ Dwi Rohman Soleh, Universitas PGRI Madiun
}

liawidyastuti33@gmail.com

\begin{abstract}
Abstrak: Penelitian ini bertujuan untuk: 1) menemukan perbedaan kemampuan menulis puisi siswa kelas IV antara siswa yang diajar dengan pendekatan kontekstual dan pendekatan behavioristik. 2) menemukan perbedaan kemampuan menulis puisi siswa kelas IV antara siswa yang HOTs-nya tinggi dengan siswa yang HOTs-nya rendah. 3) menemukan interaksi antara penggunaan pendekatan pembelajaran dan keterampilan berfikir tingkat tinggi dalam mempengaruhi kemampuan menulis puisi siswa kelas IV SDN. Penelitian ini menggunakan metode kuasi eksperimental. Penelitian dilaksanakan di SDN Se Gugus I Kecamatan Karanganyar Kabupaten Ngawi tahun ajaran 2021/2022, mulai bulan Juli 2021 sampai dengan bulan November 2021. Instrumen penelitian berupa tes untuk memperoleh data keterampilan berpikir tingkat tinggi dan untuk mengetahui kemampuan menulis puisi. Analisis data dilakukan dengan menggunakan teknik analisis varians klasifikasi ganda. Hasil analisis data model pembelajaran diperoleh nilai Fh sebesar 25,71 dan nilai signifikansi sebesar 0,000 < 0,05, dengan kesimpulan Ho ditolak. Hasil analisis variabel kemampuan berpikir tingkat tinggi diperoleh nilai Fh sebesar 169,62 dan nilai signifikansi sebesar $0,000<0,05)$. Hasil analisis interaksi model pembelajaran dan keterampilan berpikir tingkat tinggi diperoleh Fh sebesar 5,31 dan nilai signifikansi sebesar 0,020<0,05). Penelitian menyimpulkan: 1) ada perbedaan kemampuan menulis puisi siswa yang diajar dengan pendekatan kontekstual dan siswa yang diajar dengan pendekatan behavioristik. 2) Ada perbedaan kemampuan menulis puisi siswa yang keterampilan berpikir tingkat tinggi kategori tinggi dengan siswa yang keterampilan berpikir tingkat tinggi kategori rendah. 3) Ada interaksi antara penggunaan pendekatan pembelajaran dan keterampilan berpikir tingkat tinggi dalam mempengaruhi kemampuan menulis puisi siswa.
\end{abstract}

Kata kunci: pembelajaran kontekstual, pembelajaran behavioristik, keterampilan berpikir tingkat tinggi, kemampuan menulis puisi

Abstract: The goals of this study are to: 1) discover disparities in fourth-grade students' poetry writing abilities
between students who are taught using a contextual approach and kids who are taught using a behavioristic
method. 2) Find disparities in fourth-grade kids' poetry writing skills between those with high HOTs and those
with low HOTs. 3) Determine the impact of the utilization of learning methodologies and higher-order thinking
abilities on fourth-grade primary school students' ability to write poetry. The approach utilized in this investigation
was quasi-experimental. From July 2021 to November 2021 , the research was conducted in SDN Se Cluster I,
Karanganyar District, Ngawi Regency, for the $2021 / 2022$ academic year. The research instrument was a test that
was used to gather information on higher-order thinking skills and the capacity to produce poetry. Multiple
classification analysis of variance approaches were used to analyze the data. The data analysis of the learning
model produced an Fh value of 25.71 and a significance value of 0.000 0.05, indicating that Ho was rejected. The
Fh value of 169.62 was derived from the study of the higher order thinking ability variable, with a significance
value of $0.000<0.05$ ). The interaction analysis of learning models and higher order thinking skills yielded an Fh
of 5.31 and a significant value of 0.0200 . <05). The study indicates that: 1) students who are taught using a
contextual approach and students who are taught using a behavioristic approach have different capacities in poetry
composition. 2) Students with high-level thinking skills in the high category and students with low-level thinking
skills have different abilities to produce poetry. 3) There is a link between the utilization of learning methodologies
and higher-order thinking skills and students' poetry writing abilities.
Keywords: contextual learning, behavioristic learning, higher order thinking skills, poetry writing skills

Citation: Parmadi, E.W., Suharto, V.T., \& Soleh, D.R. (2022). Pengaruh Penggunaan Kontekstual dan Keterampilan Berpikir Tingkat Tinggi (HOTS) terhadap Kemampuan Menulis Puisi pada Siswa Kelas IV SDN 
Se-Gugus I Karanganyar Kabupaten Ngawi Tahun Ajaran 2021/2022. Wewarah: Jurnal Pendidikan Multidisipliner, 1(1), 106 - 116.

\section{(cc) EY}

Published by Program Pascasarjana Universitas PGRI Madiun. This work is licensed under the Creative Commons AttributionNonCommercial-ShareAlike 4.0 International License. 


\section{PENDAHULUAN}

Puisi sebagai karya sastra memiliki manfaat yang besar bagi kehidupan. Manfaat itu adalah puisi dapat sebagai sarana perolehan nilai moral yang dapat memperkuat kepribadian, dapat sebagai sarana katarsis/pencucian jiwa karena melalui membaca dan merenungkan makna yang terkandung di dalamnya, jiwa yang sedang kotor dapat dibersihkan, dan secara ekspresif/produktif dapat sebagai sarana penyampaian ide, gagasan, pesan, bahkan kritik sosial agar ditanggapi oleh pembaca. Karena demikian besar manfaat puisi, maka perlu diajarkan di sekolah dengan baik dan optimal.

Tujuan pembelajaran menulis puisi adalah salah satunya membantu siswa mengembangkan wawasan pengembangan kosakata, dengan belajar menulis puisi maka siswa akan belajar menyampaikan pikirannya dengan baik dan bisa dimengerti oleh orang lain dengan penuh penghayatan. Menurut Kurikulum 2013, secara tegas dikemukakan bahwa kegiatan menulis puisi bertujuan menggali dan mengembangkan kompetensi dasar siswa, yakni kompetensi menulis kreatif puisi. Pencapaian kompetensi menulis kreatif (menulis puisi) dapat diukur berdasarkan indikator pembelajarannya, yakni siswa mampu menulis puisi yang berisi gagasan sendiri dengan menampilkan pilihan kata yang tepat dan rima yang menarik untuk menyampaikan maksud/ide (Depdiknas, 2013: 13). Selain itu, pembelajaran menulis puisi dimaksudkan agar siswa terdidik menjadi manusia yang berkepribadian sopan dan beradab, berbudi pekerti yang halus, memiliki rasa kemanusiaan, berkepedulian sosial, memiliki apresiasi budaya dan penyaluran gagasan, berimajinasi, berekspresi secara kreatif baik secara lisan maupun tertulis serta meningkatkan kemampuan siswa dalam menikmati, mengahayati, dan memahami karya puisi.

Tujuan tersebut diharapkan dapat tercapai secara optimal. Namun sampai dewasa ini tujuan tersebut belum dapat dicapai seperti yang diharapkan. Hal itu terbukti antara lain dengan kenyataan minat siswa rendah, siswa masih belum memiliki kemampuan mancari dan menuangkan ide atau gagasan untuk menulis puisi. Salah satu kendala yang berkaitan dengan rendahnya minat siswa dalam menulis puisi adalah karena dianggap pembelajaran menulis puisi merupakan suatu pelajaran yang sulit untuk dipelajari. Pada saat pembelajaran menulis puisi, siswa merasa dihadapkan pada sebuah pekerjaan berat yang sering menimbulkan rasa was-was, bimbang, dan ragu karena merasa tidak berbakat. Keadaan ini ditandai dengan kenyataan bahwa siswa seringkali membutuhkan waktu lama ketika ditugasi untuk menulis sebuah puisi. Ini terjadi karena kemampuan siswa dalam menggali imajinasi masih sangat terbatas.

Bukti lain sebagai akibat kondisi ini, rata-rata nilai pengetahuan tentang sastra siswa masih rendah. Nilai rata-rata siswa hanya sekitar 65 , prestasi pelajaran bahasa Indonesia secara umum hanya sekitar 68. Hal ini banyak faktor yang kemungkinan menjadi penyebabnya, diantaranya adalah dukungan buku sastra di perpustakaaan sangat kurang, rendahnya budaya membaca pada siswa, selama ini guru hanya mengandalkan metode ceramah yang membosankan siswa. Kondisi buruk ini makin diperparah dengan adanya pandemi virus covid 19 yang merebak hingga saat ini. Untuk mencegah penularan, maka proses pembelajaran dilaksanakan secara daring. Akibat dari kebijakan ini interaksi pembelajaran menjadi semakin sulit, guru tidak dapat membimbing siswa sebagaimana biasanya secara langsung atau tatap muka.

Guru harus memiliki banyak alternatif untuk memecahkan masalah ini. Insan pendidik harus berusaha mencari alternatif solusi yang dapat mengatasi masalah. Salah satunya ialah perlu dicobanya berbagai ide gagasan, konsep pemikiran, pendekatan pembelajaran, model pembelajaran dan lain sebagainya agar dapat dikertahui keefektifannya di lapangan. Salah satu dari konsep pemikiran itu ialah pendekatan pembelajaran kontekstual. Pendekatan pembelajaran kontekstual adalah pendekatan pembelajaran yang memiliki banyak keunggulan yang diduga cocok untuk mengatasi kesulitan dewasa ini. Sehingga secara rinci alasan pemilihan pendekatan kontekstual tersebut dengan pertimbangan antara lain. Pertama, pendekatan kontekstual adalah suatu pendekatan yang menghubungkan materi yang diajarkan dengan situasi dunia nyata siswa. Hal tersebut dapat menolong siswa melihat makna di dalam materi akademik dengan cara menghubungkan subjek-subjek akademik dengan konteks kehidupan keseharian mereka, yaitu konteks keadaan pribadi, sosial, dan budaya Kedua, pembelajaran kontekstual bukan hanya mengajarkan siswa belajar bahasa melainkan juga lingkungan keseharian mereka. Dengan kata lain, lingkungan fisik dan psikis dibermaknakan bagi siswa. Ketiga, pembelajaran dengan pendekatan kontekstual dapat mendukung pembelajaran yang lebih menyenangkan karena siswa dilibatkan secara langsung dalam pembelajaran. Keempat, pendidik akan lebih termotivasi untuk 
mencari media pembelajaran baru dari berbagai sumber karena pendekatan kontekstual mengarahkan pendidik untuk menggunakan media pembelajaran yang lebih bervariasi. Hal tersebut dilakukan untuk meningkatkan minat dan motivasi siswa selama pembelajaran berlangsung. Kelima, dengan menggunakan pendekatan kontekstual, siswa langsung dihadapkan pada situasi dunia nyata yang dihadapinya sehingga siswa akan terangsang untuk mengungkapkan ide mereka (Johnson, 2009: 67).

Selanjutnya (Sudarisman, 2010: 10) menyatakan bahwa pendekatan kontekstual memiliki tujuh komponen utama, yaitu konstruktivisme (contructivism), inkuiri (inquiry), bertanya (questioning), masyarakat belajar (learning community), pemodelan (modeling), refleksi (reflection), penilaian sebenarnya (authentic assesment). Sebuah kelas dikatakan menggunakan pendekatan kontekstual, jika menerapkan kejutuh prinsip tersebut dalam pembelajarannya. Pendekatan kontekstual ini dapat diterapkan dalam kurikulum apa saja, bidang studi apa saja, dan kelas bagaimanapun keadaannya. Dari penjelasan diatas secara riil nanti dapat keketahui keefektifannya melalui telaah dan penelitian dan diharapkan dapat digunakan untuk mengatasi masalah dewasa ini.

Selain pendekatan pembelajaran, variabel atributif siswa yang ikut mempengaruhi proses dan hasil belajar menulis puisi antara lain ialah keterampilan berfikir tingkat tinggi yang disingkat HOTS yang variabel ini diangkat menjadi isu mutakhir dalam kompetensi dasar dalam menyikapi revolusi industri abad 21. Keterampilan berfikir tingkat tinggi atau Higher Order Thinking Skills (HOTS) merupakan keterampilan yang saat ini sangat penting utuk dikembangkan dalam pembelajaran. Hasil penelitian menunjukkan bahwa kemampuan berfikir tingkat tinggi siswa dalam pembelajaran membantu anak lebih sadar akan pemikiran mereka sendiri dan juga mendorong pembelajaran sesuai kinerja dan pertumbuhan kognitifnya. Kemampuan kognitif utamanya berfikir tingkat tinggi sangat penting dalam pendidikan baik untuk kesuksesan akademik maupun sebagai bekal di masyarakat. Wardana (dalam Nana Mardiana, 2010: 1627) mengungkapkan bahwa kemampuan berfikir tingkat tinggi adalah proses berfikir yang melibatkan aktifitas mental dalam usaha mengeksplorasi pengalaman yang kompleks, reflektif, dan kreatif yang dilakukan secara sadar untuk mencapai tujuan, yaitu memperoleh pengetahuan yang meliputi tingkat berfikir analitis, sintesis, dan evaluatif. Permendikbud Nomor 21 tahun 2016 tentang standar isi pendidikan dasar dan menengah menyatakan secara eksplisif bahwa capaian pembelajaran ranah pengetahuan meliputi taksonomi Bloom yang telah direvisi oleh Lorin Anderson dan David terdiri atas kemampuan mengingat, memahami, menerapkan, menganalisis, mengevaluasi, dan menciptakan. Sesuai dengan taksonomi tersebut dimensi proses kognitif HOTS yakni menganilisis, mengevaluasi, dan menciptakan. Soal-soal HOTS pada umumnya mengukur kemampuan pada ranah menganalisis, mengevaluasi, dan menciptakan. Tinggi rendahnya HOTS siswa sangat mempengaruhi proses dan hasil belajar siswa.

Berdasarkan latar belakang masalah di atas, maka penelitian ini memiliki tujuan sebagai berikut: 1) Untuk menemukan adanya perbedaan kemampuan menulis puisi siswa kelas IV SDN Se Gugus I Kecamatan Karanganyar Kabupaten Ngawi tahun ajaran 2021/2022 antara siswa yang diajar dengan pendekatan kontekstual dengan siswa yang diajar dengan pendekatan behavioristik. 2) Untuk menemukan adanya perbedaan kemampuan menulis puisi siswa kelas IV SDN Se Gugus I Kecamatan Karanganyar Kabupaten Ngawi tahun ajaran 2021/2022 antara siswa yang HOTs-nya tinggi dengan siswa yang HOTs-nya rendah. 3) Untuk menemukan adanya interaksi antara penggunaan pendekatan kontekstual dan keterampilan berfikir tingkat tinggi dalam mempengaruhi kemampuan menulis puisi siswa kelas IV SDN Se Gugus I Kecamatan Karanganyar Kabupaten Ngawi tahun ajaran 2021/2022.

\section{Kerangka Konseptual}

Kerangka konseptual dalam penelitian ini digambarkan sebagai berikut:

Gambar 1. Efek 1 Penggunaan Pendekatan Pembelajaran Kontekstual Dan Pendekatan Behavioristik 
Kerangka berfikir

\begin{tabular}{|c|c|}
\hline Kontekstual & Behavioristik \\
\hline $\begin{array}{l}\text { 1. Siswa yang di ajar dengan pendekatan } \\
\text { Kontekstual akan memiliki kreativitas } \\
\text { lebih tinggi dalam menulis puisi } \\
\text { 2. Siswa yang di ajar dengan pendekatan } \\
\text { Kontekstual akan memiliki kemampuan } \\
\text { berfikir kritis lebih tinggi dalam } \\
\text { menulis puisi } \\
\text { 3. Siswa yang di ajar dengan pendekatan } \\
\text { Kontekstual akan memiliki kemampuan } \\
\text { membuat keputusan lebih cepat dalam } \\
\text { menulis puisi }\end{array}$ & $\begin{array}{l}\text { 1. Siswa yang di ajar dengan pendekatan } \\
\text { Behavioristik akan memiliki kreativitas } \\
\text { lebih rendah dalam menulis puisi } \\
\text { 2. Siswa yang di ajar dengan pendekatan } \\
\text { Behavioristik akan memiliki } \\
\text { kemampuan berfikir kritis lebih rendah } \\
\text { dalam menulis puisi } \\
\text { 3. Siswa yang di ajar dengan pendekatan } \\
\text { Behavioristik akan memiliki } \\
\text { kemampuan membuat keputusan lebih } \\
\text { lambat dalam menulis puisi }\end{array}$ \\
\hline
\end{tabular}

Perbedaan proses dan hasil kegiatan menulis puisi

Gambar 2. Efek 2 tingkat kemampuan HOTS

Kerangka berfikir

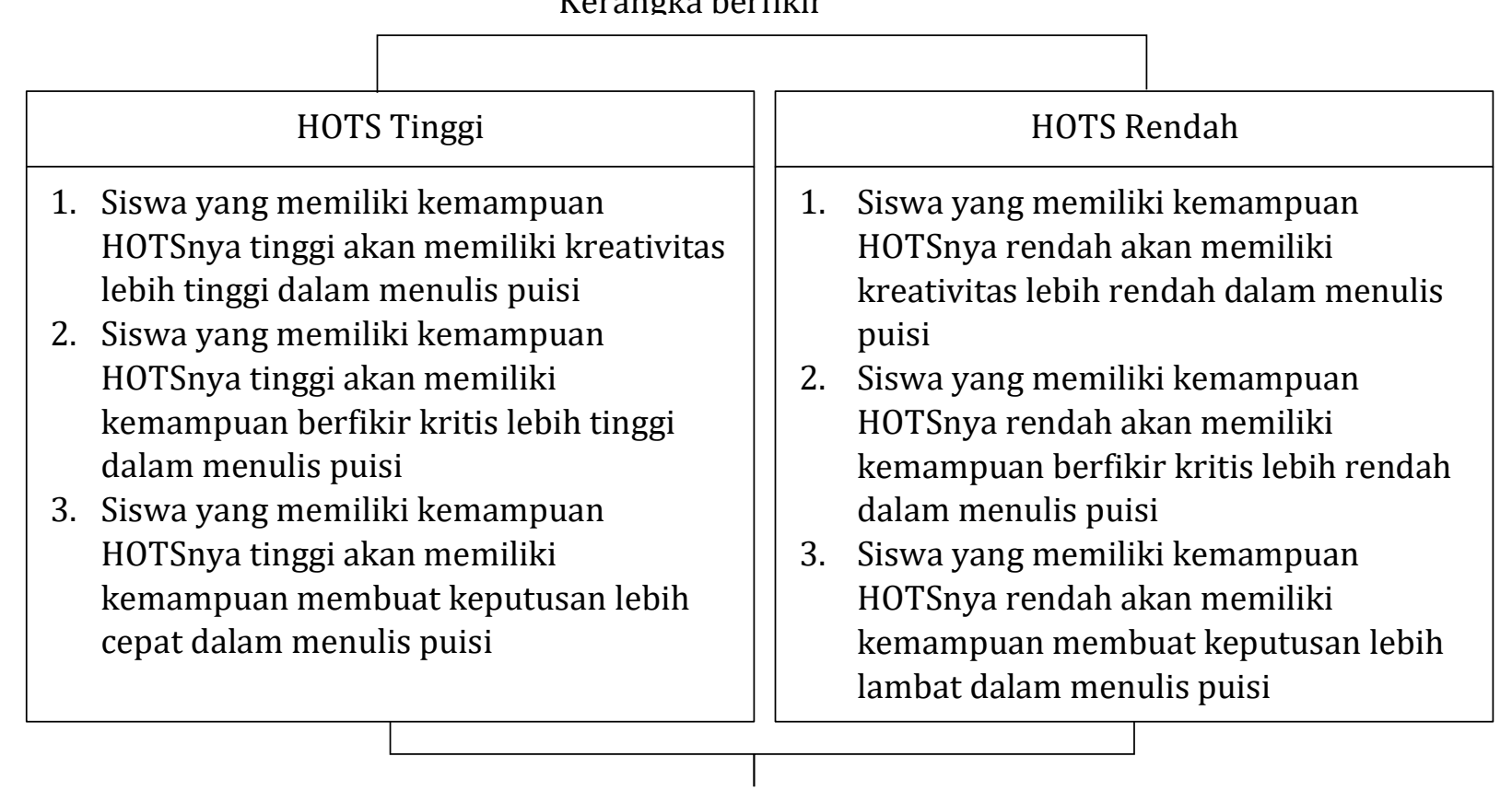

Perbedaan proses dan hasil kegiatan menulis puisi

Gambar 3. Efek 3 penggunaan pendekatan kontekstual dan tingkat kemampuan HOTS 


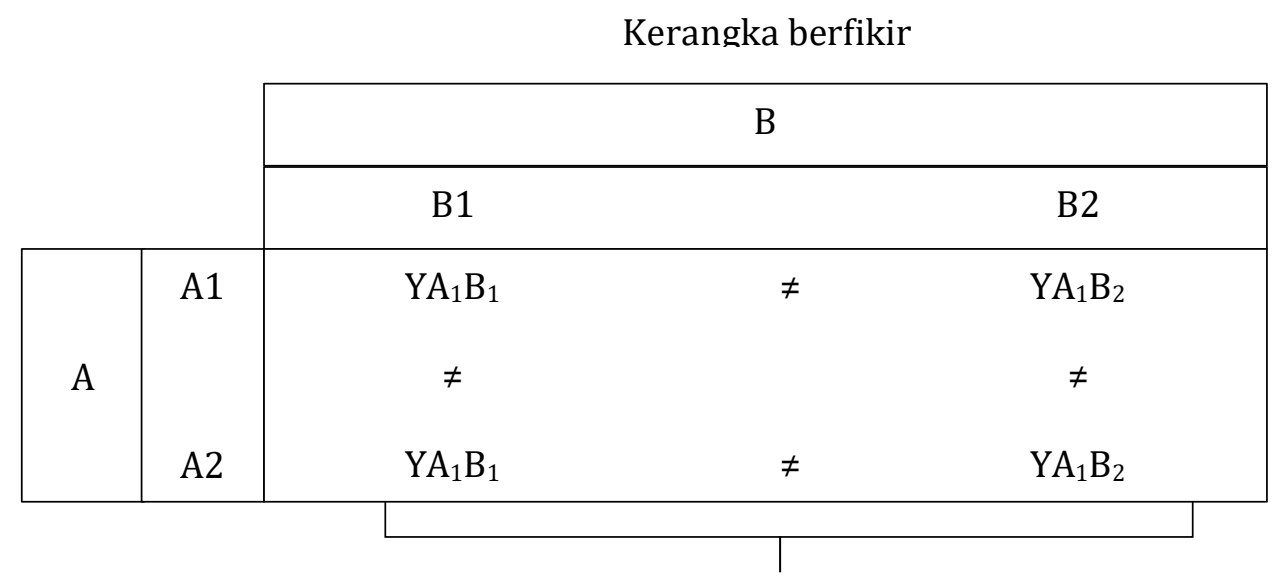

Perbedaan proses dan hasil menulis puisi

\section{METODE}

Penelitian ini dilaksanakan di Sekolah Dasar Negeri Se Gugus 1 Kecamatan Karanganyar Kabupaten Ngawi. Penelitian ini dilaksanakan mulai bulan Juli 2021 sampai dengan bulan November 2021. Penelitian ini menggunakan rancangan desain faktorial 2 X 2 . Metode penelitian ini menggunakan quasi eksperiment atau eksperimen semu.

Variabel bebas pertama ialah penggunaan model pembelajaran yang terdiri dari model pembelajaran kontekstual dan model behavioristik. Variabel bebas kedua ialah keterampilan berpikir tingkat tinggi (HOTS) yang terdiri dari level tinggi dan rendah. Variabel terikat ialah kemampuan menulis puisi.

Populasi berjumlah 209 siswa yang berasal dari 9 Sekolah. Sampel penelitian terdiri dari empat SD. Dipilih 4 SD yang memiliki kualitas siswa yang seimbang. Teknik sampling yang digunakan ialah multyple stage purposive sampling. 2 SD diberi perlakuan dengan pembelajaran kontekstual dan 2 SD yang lain diajar dengan model pembelajaran behavioristik. Instrumen penelitian ini menggunakan tes, dan dokumen. Tes digunakan untuk memperoleh data keerampilan berpikir tingkat tinggi dan untuk memperoleh data kemampuan menulis puisi. Dokumen digunakan untuk memperoleh data populasi penelitian.

Teknik analisis data dalam penelitian meliputi analisis univariat dan bivariat. Analisis univariat dilakukan untuk menganalisis variabel-variabel penelitian. Analisis bivariat digunakan untuk pengujian hipotesis, yang meliputi uji prasyarat analisis yang terdiri dari uji normalitas dan uji homogenitas. Selanjutnya uji hipotesis menggunakan rumus analisis varians klasifikasi ganda.

\section{HASIL PENELITIAN}

Analisis data kemampuan menulis puisi dengan pendekatan kontekstual sebanyak 68 siswa; diperoleh nilai minimal (min) sebesar 69; nilai maksimal (max) sebesar 96; rata-rata (Mn) sebesar 83,4; harga pertengahan $(\mathrm{Me})$ sebesar 84; varian $\left(\mathrm{S}^{2}\right)$ sebesar 54,36; standar deviasi $(\mathrm{S})$ sebesar 7,37. Analisis kemampuan menulis puisi dengan pendekatan behavioristik sebanyak 52 siswa; diperoleh nilai minimal ( $\min )$ sebesar 75; nilai maksimal $(\max )$ sebesar 98; rata-rata $(\mathrm{Mn})$ sebesar 86,67; harga pertengahan (Me) sebesar 87; varian $\left(\mathrm{S}^{2}\right)$ sebesar 35,48; standar deviasi (S) sebesar 5,96. Analisis kemampuan menulis puisi dengan HOTS tinggi sebanyak 64 siswa; diperoleh nilai minimal (min) sebesar 80; nilai maksimal (max) sebesar 98; rata-rata $(\mathrm{Mn})$ sebesar 89,59; harga pertengahan $(\mathrm{Me})$ sebesar 90; varian $\left(\mathrm{S}^{2}\right)$ sebesar 20,5; standar deviasi (S) sebesar 4,53. Analisis kemampuan menulis puisi dengan HOTS rendah sebanyak 56 siswa; diperoleh nilai minimal (min) sebesar 69; nilai maksimal (max) sebesar 90; rata-rata $(\mathrm{Mn})$ sebesar 79,36; harga pertengahan $(\mathrm{Me})$ sebesar 80; varian $\left(\mathrm{S}^{2}\right)$ sebesar 24,49; standar deviasi (S) sebesar 4,95. 
Perbandingan rata-rata siswa untuk masing-masing kelompok siswa berdasarkan model pembelajaran dan kategori keterampilan berpikir tingkat tinggi dapat dilihat sebagai berikut:

Tabel 1. Nilai Rata-rata Kemampuan menulis puisi siswa berdasarkan model pembelajaran dan keterampilan berpikir tingkat tinggi.

Tabel 1. Nilai Rata-rata Kemampuan menulis puisi siswa berdasarkan model pembelajaran dan keterampilan berpikir tingkat tinggi

\begin{tabular}{|c|c|c|c|c|c|}
\cline { 3 - 6 } \multicolumn{2}{c|}{} & $\begin{array}{c}\text { Model } \\
\text { kontekstual - } \\
\text { HOTS Tinggi }\end{array}$ & $\begin{array}{c}\text { Model } \\
\text { kontekstual - } \\
\text { HOTS Rendah }\end{array}$ & $\begin{array}{c}\text { Model } \\
\text { behavioristik- } \\
\text { HOTS Tinggi }\end{array}$ & $\begin{array}{c}\text { Model } \\
\text { behavioristik- } \\
\text { HOTS Rendah }\end{array}$ \\
\hline \multirow{2}{*}{$\begin{array}{c}\text { Kemampuan } \\
\text { Henulis puisi }\end{array}$} & $\mathrm{Mn}$ & 83,40 & 86,67 & 90,35 & 79,81 \\
\cline { 2 - 6 } & $\mathrm{S}$ & 7,37 & 5,96 & 6,26 & 5,76 \\
\hline
\end{tabular}

Hasil uji prasyarat analisis, terdiri dari uji normalitas dan uji homogenitas, hasilnya dapat dilihat pada tabel-tabel di bawah ini.

Tabel 2 : Hasil Uji Normalitas Hasil Belajar

\begin{tabular}{|c|l|c|c|}
\cline { 3 - 4 } \multicolumn{2}{c|}{} & $\begin{array}{c}\text { Kolmogorov-Smirnov } \\
Z\end{array}$ & $\begin{array}{c}\text { Asymp. Sig. } \\
\text { (2 tiled) }\end{array}$ \\
\hline \multirow{3}{*}{ Sel } & A1-B1 & 0,093 & 0,200 \\
\cline { 2 - 4 } & A1-B2 & 0,092 & 0,200 \\
\cline { 2 - 4 } & B2-B1 & 0,126 & 0,200 \\
\cline { 2 - 4 } & A2-B2 & 0,122 & 0,200 \\
\hline
\end{tabular}

Hasil uji normalitas data kemamuan menulis puisi siswa yang diajar dengan model pembelajaran kontekstual dan behavioristik dengan HOTS tinggi dan HOTS rendah dengan rumus Kolmogorov Smirnov diperoleh harga signifikansi $>0,05$. Karena itu disimpulkan bahwa data masing-masing kelompok penelitian berdistribusi normal.

Tabel 3 : Rangkuman Uji Homogenitas Levene,s

\begin{tabular}{|c|c|c|c|}
\hline $\mathrm{F}$ & $\mathrm{df} 1$ & $\mathrm{df} 2$ & signifikansi \\
\hline 0,307 & 3 & 116 & 0,821 \\
\hline
\end{tabular}

Tabel di atas menunjukkan bahwa nilai signifikansi 0,821 lebih besar dari taraf signifikansi $0,05(0,821$ $>0,05)$. Dengan demikian Ho tidak ditolak yang berarti semua kelompok data tersebut variannya homogen.

Tabel 4 : Rangkuman Hasil Pengujian Hipotesis

\begin{tabular}{|l|r|r|r|r|r|}
\hline \multicolumn{1}{|c|}{ Source } & Type III Sum of Squares & \multicolumn{1}{c|}{ df } & Mean Square & \multicolumn{1}{c|}{ F } & \multicolumn{1}{c|}{ Sig. } \\
\hline Corrected Model & 3670,37 & 3 & 1223,46 & 67,66 & 0,00 \\
\hline Intercept & 840094,15 & 1 & 840094,15 & 46458,34 & 0,00 \\
\hline Model_Pembelajaran & 464,99 & 1 & 464,99 & 25,71 & 0,00 \\
\hline HOTS & 3067,21 & 1 & 3067,21 & 169,62 & 0,00 \\
\hline Model_Pembelajaran * & 95,99 & 1 & 95,99 & 5,31 & 0,02 \\
HOTS & 2097,60 & 116 & 18,08 & & \\
\hline Error & 869032 & 120 & & & \\
\hline Total & 5767,9667 & 119 & & & \\
\hline Corrected Total & & & & \\
\hline
\end{tabular}

Hasil analisis statistik Anava dua jalan dengan univariate analysis of variance, untuk variabel model pembelajaran didapatkan nilai $\mathrm{F}$ hitung sebesar 25,71 dan nilai signifikansi sebesar 0,000 . Setelah nilai signifikansi dikonsultasikan dengan taraf signifikansi 0,05 , diketahui nilai signifikansi 0,000 lebih kecil dibanding 0,05 $(0,000<0,05)$. Dari hasil analisis tersebut, maka Ho yang menyatakan "tidak ada perbedaan kemampuan menulis puisi yang diajar dengan metode Pembelajaran kontekstual dan Siswa yang diajar dengan metode pembelajaran behavioristik" ditolak, dan $\mathrm{H}_{1}$ yang menyatakan "ada perbedaan kemampuan menulis puisi siswa yang diajar 
dengan metode Pembelajaran kontekstual dan siswa yang diajar dengan metode pembelajaran behavioristik", dapat diterima. Hal ini berarti bahwa ada perbedaan kemampuan menulis puisi siswa yang diajar dengan metode pembelajaran kontekstual dan siswa yang diajar dengan metode pembelajaran behavioristik".

Hasil analisis statistik Anava dua jalan dengan univariate analysis of variance untuk variabel keterampilan berpikir tingkat tinggi didapatkan nilai $\mathrm{F}$ hitung sebesar 169,62 dan nilai signifikansi sebesar 0,000. Setelah nilai signifikansi dikonsultasikan dengan taraf signifikansi 0,05, diketahui nilai signifikansi 0,000 lebih kecil dibanding $0,05(0,000<0,05)$. Dari hasil analisis tersebut, maka Ho yang menyatakan "tidak ada perbedaan kemampuan menulis puisi Siswa yang memiliki keterampilan berpikir tingkat tinggi dengan kategori tinggi dengan Siswa yang memiliki keterampilan berpikir tingkat tinggi kategori rendah" ditolak, dan $\mathrm{H}_{1}$ yang menyatakan "ada perbedaan kemampuan menulis puisi Siswa yang memiliki keterampilan berpikir tingkat tinggi dengan kategori tinggi dengan Siswa yang memiliki keterampilan berpikir tingkat tinggi kategori rendah"" diterima. Hal ini berarti bahwa ada perbedaan Hasil Belajar Siswa yang memiliki keterampilan berpikir tingkat tinggi kategori tinggi dengan Siswa yang memiliki kategori rendah.

Hasil analisis statistik Anava dua jalan dengan univariate analysis of variance interaksi model pembelajaran dan keterampilan berpikir tingkat tinggi didapatkan nilai $\mathrm{F}$ hitung sebesar 5,31 dan nilai signifikansi sebesar 0,02 . Setelah nilai signifikansi dikonsultasikan dengan taraf signifikansi 0,05, diketahui nilai signifikansi 0,02 lebih kecil dibanding 0,05 $(0,02<0,05)$. Dari hasil analisis tersebut, maka Ho yang menyatakan "tidak ada interaksi antara penggunaan model pembelajaran dan keterampilan berpikir tingkat tinggi dalam mempengaruhi kemampuan menulis puisi" ditolak, dan $\mathrm{H}_{1}$ yang menyatakan "ada interaksi antara penggunaan model pembelajaran dan keterampilan berpikir tingkat tinggi dalam mempengaruhi kemampuan menulis puisi" diterima. Hal ini berarti bahwa ada interaksi antara penggunaan model pembelajaran dan keterampilan berpikir tingkat tinggi dalam mempengaruhi kemampuan menulis puisi.

\section{PEMBAHASAN}

\section{Perbedaan Kemampuaan Menulis Puisi Siswa dengan Model Pembelajaran Kontekstual dengan Model Pembelajaran Behavioristik}

Pembelajaran kontekstual merupakan pembelajaran yang mengutamakan kegiatan pada siswa yang mana siswa menghubungkan pengetahuan yang diperoleh dari guru di sekolah dan menghubungkan dengan situasi yang nyata. Jika materi pembelajaran tentang perilaku, maka siswa akan menghubungkan pengetahuan yang didapat di sekolah tentang perilaku kemudian mengkaitkannya dengan perilaku yang ada di lingkungannya. Dengan menghubungkan pengetahuan dengan keadaan yang nyata di sekelilingnya, maka dapat diharapkan terbentuk pengetahuan yang benar-benar dapat dipahami oleh siswa. Dengan membandingkan pengetahuan yang didapat dengan keadaan yang nyata, maka konsep pengetahuan akan benar-benar membekas dalam ingatan siswa.

Sementara itu, pembelajaran behavioristik merupakan pembelajaran yang dilakukan dengan pengkondisian lingkungan belajar agar perilaku siswa dapat berubah sesuai dengan tujuan pembelajaran. Dalam hal ini guru melakukan pengkondisian lingkungan belajar siswa. Dengan mengkondisikan lingkungan, maka situasi dapat dikendalikan dengan baik dan tentunya pengkondisian disesuaikan dengan keadaan siswa terkait dengan materi yang sedang dipelajari.

Berdasarkan penjelasan di atas, penelitian ini membandingkan kedua model pendekatan pembelajaran kontekstual dan behavioristik. Dari hasil analisis data yang diperoleh dari siswa, disimpulkan kedua model pendekatan dalam penelitian ini memiliki perbedaan yang signifikan $(\mathrm{Fh}=25,71$; sig: $0,000<0,05)$. Dari hasil penelitian juga dapat diketahui bahwa rata-rata hasil belajar siswa dengan model pendekatan kontekstual sebesar 82,69 lebih kecil dibanding dengan hasil belajar siswa dengan model pendekatan behavioristik sebesar 89,67. Dengan demikian dapat dinyatakan bahwa pendekatan behavioristik lebih baik dibandingkan dengan pendekatan kontekstual.

Pembelajaran kontekstual adalah konsep belajar yang mana guru menghadirkan dunia nyata ke dalam kelas dan membimbing siswa membuat hubungan keterkaiatan antara pengetahuan yang dimiliki dengan penerapannya dalam kehidupan sehari- hari, namun siswa memperoleh 
pengetahuannya tidak secara langsung banyak tetapi bertahap dan terbatas dari pengkontruksian sendiri sebagai bekal untuk memecahkan masalah dalam kehidupan sehari- hari.

Pendekatan pembelajaran kontekstual lebih mengutamakan aktifitas siswa dalam pembelajaran sehingga siswa dapat menemukan konsep tentang materi pembelajaran dan mengaitkan konsep tersebut dengan situasi dunia nyata mereka, adanya interaksi antara siswa dengan guru sebagai pengelola kelas, siswa dengan siswa karena bekerjasama dalam tim untuk menemukan sesuatu yang baru, siswa dengan berbagai sumber belajar dan menggunakan panca indera untuk memberikan pengalaman belajar yang bermakna.

Contextual Teaching and Learning merupakan suatu proses pendidikan yang holistik dan bertujuan memotivasi siswa. Pembelajaran ini digunakan untuk memahami makna materi pelajaran yang sedang dipelajari dalam konteks kehidupan sehari-hari siswa (konteks pribadi, sosial, dan kultural), sehingga siswa memiliki pengetahuan yang secara fleksibel dapat diterapkan dari satu konteks ke konteks lainnya (Aqib, 2013: 4).

Dengan pendekatan pembelajaran kontekstual siswa akan memperoleh pengetahuan dan ketrampilan sebagai bekal untuk memecahkan masalah kehidupannya di lingkungan masyarakat. Siswa adalah generasi yang dipersiapkan untuk menghadapi dan memecahkan masalah di masa mendatang sehingga perlu dilatih dari sekarang.

\section{Ada Perbedaan Kemampuaan Menulis Puisi Siswa yang Memiliki Keterampilan Berpikir Tingkat Tinggi dengan Kategori Tinggi dan Siswa yang Memiliki Keterampilan Berpikir Tingkat Tinggi dengan Kategori Rendah}

Keterampilan berpikir tingkat tinggi merupakan kemampuan dalam menerapkan analisis dalam mengingat, menyatakan kembali, atau merujuk pada suatu hal dalam menyelesaikan suatu permasalahan. Keterampilan berpikir tingkat tinggi merupakan suatu kegiatan dalam mengambil suatu keputusan karena adanya suatu masalah. Sebagai kegiatan mengambil keputusan, maka dibutuhkan kemampuan berpikir berdasarkan informasi yang ada, mengolah informasi, memilah informasi yang berkaitan dengan permasalahan yang sedang dihadapi. Dengan informasi yang lengkap dan diolah sedemikian rupa sehingga keputusan yang akan diambil merupakan keputusan yang matang berdasarkan informasi yang lengkap.

Kemampuan berpikir tingkat tinggi dalam penelitian ini diktegorikan menjadi 2 yaitu kategori tinggi dan rendah. Kemampuan berpikir tingkat tinggi dengan kategori tinggi tentunya berbeda dengan kemampuan berpikir tingkat tinggi dengan kategori rendah. Hal ini ditunjukkan juga dari hasil penelitian dengan perolehan harga $F$ hitung sebesar 169,62 dengan signifikansi sebesar $0,00<0,05$, menunjukkan ada perbedaan yang signifikan kemampuan menulis puisi siswa yang memiliki keterampilan berpikir tingkat tinggi dengan kategori tinggi dengan siswa yang memiliki keteampilan berpikir tingkat tinggi dengan kategori rendah. Perbedaan yang signifikan tersebut juga ditunjukkan besarnya nilai rata-rata kemampuan menulis puisi siswa yang termasuk kategori tinggi sebesar 89,798 dan siswa yang termasuk kategori rendah sebesar 79,564. Dengan demikian juga dapat dinyatakan bahwa siswa yang memiliki keterampilan berpikir tingkat tinggi dengan kategori tinggi lebih baik dibandingkan dengan siswa dengan keterampilan berpikir tingkat tinggi dengan kategori rendah.

Secara garis besar Resnick (1987) mengutarakan bahwa kemampuan berfikir tingkat tinggi merupakan suatu pemikiran yang kompleks dengan melibatkan berbagai sumber dan kriteria sehingga dapat menyelesaikan masalah. Haladyna (1997) menjelaskan bahwa kompleksitas berfikir dan dimensi belajar diklasifikasikan menjadi empat level proses mental, yaitu pemahaman, kemampuan memecahkan masalah, dapat berfikir kritis dan berfikir kreatif yang dapat diaplikasikan pada empat konten yaitu fakta, konsep, prinsip pokok, dan prosedur. Menggunakan serangkaian kemapuan tersebut merupakan sebuah proses pemikiran tingkat tinggi.

Siswa yang memiliki kemampuan berfikir level tinggi, dapat melakukan suatu analisis pada suatu permasalahan yang sedang dihadapi. Analisis merupakan kemampuan memecah sesuatu menjadi beberapa bagian dan dapat mengetahui hubungan antar bagian tersebut (Anderson \& Krathwohl, 2001: 79). Kemampuan analisis juga merupakan kemampuan untuk menguraikan sesuatu. Kemampuan analisis diklasifikasikan menjadi tiga yakni membedakan, mengorganisasi, dan mengatribusikan (Anderson \& Krathwohl, 2001: 79). Kemampuan perpikir analisis disebut juga kemampuan level $\mathrm{C} 4$, siswa mampu memecahkan masalah dan menghubungkan suatu konsep 
terhadap keputusan yang akan diambil (Anderson \& Krathwohl, 2001). Siswa yang terlatih mengerjakan soal tipe $\mathrm{C} 4$ dikategorikan memiliki pemahaman yang dalam sehingga mampu berfikir analitis dan dapat mengaplikasiaknnya pada suatu masalah yang baru (Ramos et al, 2013).Menurut Newman dan Wehlage (Widodo, 2013: 162) dengan high order thinking skills siswa akan dapat membedakan ide atau gagasan secara jelas, berargumen dengan baik, mampu memecahkan masalah, mampu mengkonstruksi penjelasan, mampu berhipotesis dan memahami hal-hal kompleks menjadi lebih jelas. Menurut Kurniati (2014: 62) high order thinking skills akan terjadi ketika seseorang mengaitkan informasi baru dengan informasi yang sudah tersimpan di dalam ingatannya dan mengaitkannya dan/atau menata ulang serta mengembangkan informasi tersebut untuk mencapai suatu tujuan atau menemukan suatu penyelesaian dari suatu keadaan yang sulit dipecahkan.

Penelitian "Pengaruh Pendekatan High Order Thinking Skill (Hots) Terhadap Kemampuan Menulis Teks Eksplanasi" oleh Rukmini, Sudrajat, dan Latifah menghasilkan temuan bahwa Higher Order Thinking Skills mampu meningkatkan kemapuan menulis teks eksplanasi siswa kelas VII B AMPN 2 Margasih (2021). Hal yang sama juga ditemukan dalam penelitian "Pengaruh Strategi Pembelajaran Higher Order Thinking Terhadap Kemampuan Menulis Teks Anekdot Siswa Kelas X SMA Negeri 1 Telukdalam" dimana penerapan HOT (Higher Order Thinking) berpengaruh positif terhadap hasil belajar siswa kelas X SMA Negeri 1 Telukdalam T.A. 2017/2018 (Zalukhu, 2018). "Kemampuan Berpikir Kritis Siswa dalam Menyelesaikan Soal Higher Order Thinking Skills pada Kelas V Materi IPA" di SDN Mangkubumen Lor No. 15 Surakarta oleh Puspitasari dan Saputri menunjukkan bahwa aplikasi pertanyaan-pertanyaan HOTS untuk mengukur keterampilan berpikir kritis bisa berhasil dengan baik dan secara tidak langsung bisa menjadikan siswa berpikir kritis dalam menghadapi pemecahan masalah (2021).

Penelitian "Penerapan Model Pembelajaran Problem Based Learning dengan Multimedia untuk Meningkatkan Kemampuan Menulis Puisi Siswa" oleh Kusrianti dan Suharto (2019) menemukan bahwa menerapkan model pembelajaran PBL dengan multimedia dapat meningkatkan kemampuan menulis puisi siswa kelas VIII SMP Negeri 1 Pangkur Kecamatan Pangkur Kabupaten Ngawi. Hal yang sama juga ditemukan dalam penelitian "Penggunaan Contextual Teaching and Learning (CTL) Berbantuan Kartu Kata Untuk Meningkatkan Keterampilan Menulis Pantun Pada Siswa SD" yang menyimpulkan bahwa bahwa penggunaan pendekatan CTL berbantuan kartu kata efektif diterapkan dalam pembelajaran menulis pantun pada siswa kelas V SDN 2 Ngrayun Ponorogo (Suprapto et al., 2020).

\section{Ada Interaksi antara Penggunaan Model Pembelajaran dan Keterampilan Berfikir Tingkat Tinggi dalam Mempengaruhi Hasil Belajar}

Model pembelajaran jelas menunjukkan adanya pengaruh terhadap kemampuan siswa dalam menulis puisi. Selain itu keterampilan berpikir tingkat tinggi juga berpengaruh terhadap kemampuan siswa dalam menulis puisi. Baik model pembelajaran maupun keterampilan berpikir tingkat tinggi merupakan variabel yang keduanya berpengaruh terhadap kemampuan siswa dalam menulis puisi sebagaimana telah dikemukakan berdasarkan hasil analisis data. Karena kedua variabel tersebut berpengaruh terhadap kemampuan siswa dalam menulis puisi, maka tentunya jika kedua variabel tersebut diinteraksikan akan berpengaruh juga terhadap kemampuan siswa dalam menulis puisi.

Hasil analisis data interaksi model pembelajaran dan keterampilan berpikir tingkat tinggi dalam penelitian ini diperoleh harga $F$ sebesar 5,309 dengan signifikansi sebesar 0,023. Harga signifikansi $0,023<0,05$, artinya bahwa interaksi kedua variabel berpengaruh signifikan terhadap kemampuan menulis puisi pada siswa. Dengan adanya interaksi tersebut, maka kedua variabel bebas dalam penelitian ini merupakan variabel yang perlu dipertimbangkan dalam kegiatan pembelajaran, khususnya dalam materi menulis puisi pada pembelajaran bahasa Indonesia.

\section{SIMPULAN}

Penelitian ini memperoleh kesimpulan sebagai berikut:

Ada perbedaan kemampuan menulis puisi siswa yang diajar dengan pendekatan kontekstual dan siswa yang diajar dengan pendekatan behavioristik siswa kelas IV SDN Se-Gugus I Kecamatan 
Karanganyar Kabupaten Ngawi Tahun Ajaran 2021/2022. Dengan demikian maka hipotesis alternatif dalam penelitian ini dapat diterima.

Ada perbedaan kemampuan menulis puisi siswa yang keterampilan berpikir tingkat tinggi kategori tinggi dengan siswa yang keterampilan berpikir tingkat tinggi kategori rendah siswa kelas IV SDN Se-Gugus I Kecamatan Karanganyar Kabupaten Ngawi Tahun Ajaran 2021/2022. Dengan demikian maka hipotesis alternatif dalam penelitian ini dapat diterima.

Ada interaksi antara penggunaan pendekatan pembelajaran dan keterampilan berpikir tingkat tinggi dalam mempengaruhi kemampuan menulis puisi siswa kelas IV SDN Se-Gugus I Kecamatan Karanganyar Kabupaten Ngawi Tahun Ajaran 2021/2022. Dengan demikian maka hipotesis alternatif dalam penelitian ini dapat diterima.

\section{DAFTAR PUSTAKA}

Anderson, L. W., dan Krathwohl, D. R. (2001). A taxonomy for learning, teaching, and assesning. New York: Pre-Press Company

Aqib, Zainal. 2013. Model-model, Media, dan Strategi Pembelajaran Kontekstual. (Inovatif). Bandung: Yrama Widya.

Haladyna, T.M. (1997). Writing Test Items to Evaluate Higher Order Thinking. Boston: Allyn and Bacon

Johnson, Elaine. (2009). Contextual Teaching and Learning : Menjadikan Kegiatan Belajar Mengasikkan dan Bermakna. Bandung: Mizan Media Utama.

Kurniati, Dian., Harimukti, Romi., \& Jamil, Nur Aisyah. (2014). Kemampuan berpikir tingkat tinggi siswa SMP di kabupaten Jember dalam menyelesaikan soal berstandar PISA. Jurnal Penelitian dan Evaluasi Pendidikan, 20(2), 142-155.

Kusrianti, A., \& Suharto, V. T. (2019). Penerapan Model Pembelajaran Problem Based Learning dengan Multimedia untuk Meningkatkan Kemampuan Menulis Puisi Siswa. Linguista: Jurnal Ilmiah Bahasa, Sastra, Dan Pembelajarannya, 3(2), 145-152. https://doi.org/10.25273/linguista.v3i2.5736

Mardiana, Nana dkk. 2010. Penerapan Model Quantum Teaching Untuk Meningkatkan Hasil Belajar IPS Siswa Kelas IV SD Negeri 145 Pekanbaru. Pekanbaru: PGSD FKIP Universitas Riau.

Puspitasari, E., \& Saputri, D. Y. (2021). Kemampuan berpikir kritis siswa dalam menyelesaikan soal higher order thinking skills pada kelas v materi ipa. JPI (Jurnal Pendidikan Indonesia): Jurnal Ilmiah Pendidikan, 7(1), 48-52. https://doi.org/10.20961/jpi.v7i1.50077

Rukmini, S., Sudrajat, R. T., \& Latifah, L. (2021). PENGARUH PENDEKATAN HIGH ORDER THINKING SKILL (HOTS) TERHADAP KEMAMPUAN MENULIS TEKS EKSPLANASI. Parole (Jurnal Pendidikan Bahasa dan Sastra Indonesia), 4(1), 129-140. https://doi.org/10.22460/p.v4ilp129-140.6997

Suharto, T., \& Soleh, D. R. (2021). Peningkatan Keterampilan Menulis Cerpen Melalui Model Pembelajaran Kooperatif Type Jigsaw Berbantuan Media Audiovisual Pada Siswa Kelas XI MIPA 2 SMA Darum Ulum Poncol Magetan Tahun Pelajaran 2020

Suprapto, S., Suharto, V. T., \& Irawati, L. (2020). Penggunaan Contextual Teaching and Learning (CTL) Berbantuan Kartu Kata Untuk Meningkatkan Keterampilan Menulis Pantun Pada Siswa SD. Linguista: Jurnal Ilmiah Bahasa, Sastra, Dan Pembelajarannya, 4(1), 51-61. https://doi.org/10.25273/linguista.v4i1.6688

Zalukhu, M. C. (2018). PENGARUH STRATEGI PEMBELAJARAN HIGHER ORDER THINKING TERHADAP KEMAMPUAN MENULIS TEKS ANEKDOT SISWA KELAS X SMA NEGERI 1 TELUKDALAM. JURNAL EDUCATION AND DEVELOPMENT, 6(1), 60-60. https://doi.org/10.37081/ed.v6i1.652 